JOURNAL OF RESEARCH IN ARCHITECTURE AND PLANNING

ISSN (P) 1728-7715 - ISSN (E) 2519-5050

Journal DOI: www.doi.org/10.53700/jrap_neduet

Issue DOI: www.doi.org/10.53700/jrap3012021

\title{
URBAN LIFE IS NOTHING IF NOT THEATRICAL: THE ROLE OF ART IN THE REGENERATION OF THE MEDINA OF TUNIS CITY
}

\author{
Sarah Ben Aslem*, Amine Mseddi**, Mariann Simon***
}

\section{Article DOI:}

www.doi.org/10.53700/jrap3012021_1

\section{Article Citation:}

Aslem S. B., et. al., 2021, Urban Life is Nothing if not Theatrical: The Role of Art in the Regeneration of the Medina of Tunis City, Journal of Research in Architecture \& Planning, 30(1). 1-9.

* Ph D Student, Doctoral School of Landscape Architecture and Ecology, Hungarian University of Agriculture and Life Sciences, MATE, Hungary.

sarah.ben.salem23@gmail.com

** Ph D Student, Doctoral School of Landscape Architecture and Ecology, Hungarian University of Agriculture and Life Sciences, MATE, Hungary.

amine.mseddi.architect@gmail.com

*** CSc Professor, Doctoral School of Landscape Architecture and Ecology, Hungarian University of Agriculture and Life Sciences, MATE, Hungary. simon.marianna@szie.hu

\begin{abstract}
Arts are the main human expression encouraging man to expose his practices, ideas, and fears. This in turn affects and shapes his environment, an environment which keeps evolving into cities. Nowadays, human expression through art is playing a major role in the development of the urban landscape by shifting the oldfashioned paradigms of the rigid and static urban structuring and development, especially with the new urban trends floating on the surface. The case study of the Medina of Tunis is a paradigmatic example that illustrates the bottom- up approach of social participation in urban life through art.

The research question asked here is to what extent has the artistic practices been influencing the urban development of the city's user experience? Can this be regarded as a necessary tool for the regeneration of the historical urban landscape?

First, a general overview of urban development and the influence of the artistic practices have been presented. Issues such as urban transformation are highlighted. The second part exposes specific examples of artistic manifestations influencing public spaces and urban life in the studied example of the Medina of Tunis. The next step is about elaborating the main examples in their context in the form of case studies. The analysis of these case studies directs towards the outcomes and conclusions regarding the impact of artistic practices in changing the way a city is perceived, used and designed.
\end{abstract}

Keywords: Art, Public Space, Urbanism, Transformation, Social Participation, Medina of Tunis, Urban Heritage

\section{INTRODUCTION}

Cities are evolutive entities. They are generally characterised by a dynamic process dictated through material and immaterial factors. Societies are necessarily expressing themselves in their spaces. The city is then nothing but the field of action of its citizens. We can look at it as the canvas for the diverse expressions of the community in place (Kostof, 1991).

"In every age, urban spaces -streets and squares- have served to stage spectacles in which the citizenry participated as players and audience. Urban life is nothing if not theatrical" (Kostof, 1991: 222).

From another perspective, creative ways of using public spaces including artistic practices, are important for implementing regenerative ideas, especially in an urban fabric that becomes strewn with unused and neglected areas, disrupting the integrality of the urban plan and "often transforming the public spaces into a residual and abandoned areas" (Amato and Bevilacqva 2020:47). For this, innovative interventions are to be the "counter-transformation" to regain urban character and improve the life in the city.

\section{SOCIAL INTERACTION AS THE ORIGIN OF URBAN LIFE}

In a matter of fact, social actions events and daily activities have always been hosted by urban spaces. Therefore, the usage of these spaces has an evolutive pattern related tightly to the users. Indeed, the way cities are shaped and structured, 
perceived and lived is conditioned and even taken under the realm of social background. Spaces gain their significance and their role according to the combination of values, manners, beliefs, ideology, dogma and collective awareness of the people, in addition to other material factors such as geography, demography, land morphology and resources. For instance, the Roman city was planned as a projection of the cosmos based on their divinity and mythological narrative: divided by two main perpendicular axes (Cardo - Documanus) in the very city centre, every Cardan has its particular meaning and functions put in place in a grid structure. Yet Rome, the capital, was the absolute image of an organic city, because of the topography and geography of the region. While in the Islamic civilisation, for example, the cities structure was mainly dictated by the religious value system related to relevant concepts like intimacy, privacy, ethics, hierarchy and respect which formed a sort of social convention that ruled the urban plan. This resulted with other factors intervening, in the sprawling narrow alleys, the density and proximity of the buildings, the enclosure/opening ratio of the facades, water, and vegetation presence. The Islamic medieval city of the Medina of Tunis is characterised by an organic cellular tissue. It provides variety and originality in its architectural elements and a structural link between its components (Ben Salem, 2019). The sacred character of the Islamic culture is a preeminent impact in shaping the city. "The sacred space includes spaces that can be entered physically, imaginatively and visually" (Bandarin and Van Ores, 2014:131). Hence, this shows that the dynamic of urban space use is guided by interdependent systems reflective of social expressions.

In the light of this evolution, it can be observed that the Renaissance period had a huge impact in the way of thinking and perceiving of urban form. A lot of norms changed (culture, philosophy, humanisation, religion role, laws) and along with it, the way cities were experienced also changed. Renaissance designers and theorists draw attention to the usage of public spaces. Roads and pathways, were not just reduced to their passive role of linking the urban elements but started being considered as spatial entities, liveable and independent (Kostaf, 1991). Besides the philosophical and scientific revolution, the Renaissance was also an artistic revolution. The tremendous development of the artistic movement was mirrored in urban life too, to the extent that the famous Michel Angelo was offered the public squares of Florence to serve as open workshops for him and his apprentices. This type of action initiated a free popular movement using studios hosting sculptures, paintings, plays, and poetry. Thus, people were explicitly transforming cities through art.
The perception and use of urban and public space kept evolving gradually until the second half of the nineteenth century. The scientific society witnessed the emergence of "urbanism" as an academic term and as a proper discipline, covering the attribution, design and use of the spaces inside and outside the city. Moreover, in the context of cities evolution, different debates emerged concerned with the way with which historical patrimony should be treated, as attested by the movement of thoughts which were against the theory that the heritage must be intact and considered as a static museum. Instead, theoreticians and urban history specialists of the nineteenth century, such as the Italian Architect Giovannoni, considered the city as a "kinematic system", claiming that the city should be capable to manage the progressive augmentation of the population and the mutation of our social and physical environment. At the same time, the nobility of the city must be respected by valuing the legacy that, not only, has been transferred by our ancestors, but also, attests and embodies the evolution and meaning of human existence and the knowledge of every generation (Giovannoni, 1998).

Since 1960s, the problem of city life appears not only in urban circles, but it was touched by human scientists. With this new component in play, academics and professionals from the fields of architecture, engineering and social sciences were in the quest of finding a middle ground, a compromise to include these diverse areas of expertise in the act of city planning. In addition there was emphasis on the involvement of social aspects so the city would meet more efficiently, the community's needs, goals and strategies. This movement, criticising some axioms of the Modernist school, was led by professionals, thinkers and academics. In his book "The Production of Space", the philosopher Henry Lefebvre (1974) went to the limit of rethinking the notion of "space", its origins, and its connotations from different perspectives. Contemporary experts and practitioners in urbanism such as Gehl (2001) clearly claimed similar notions.

Kevin Lynch, one of the most popular urban theorists, treated this issue in his book "The image of the city" in the early sixties. Urban activist Jane Jacobs also highlighted the disintegration of living public spaces and the gradual transformation of the streets into useless and neglected areas (Jacob, 1960). In the seventies also, architects and city planners, such as Jacobs and Appleyard formulated several planning principles, favouring the theory of "public space for all", where city users could have more access and control of public spaces. They were persuaded that these public milieus were community-based spaces that represented an environment for all, where people could draw more life 
opportunities, imagination and joy and even feel connected to their identity (Jacobs and Appleyard, 1987). In addition to the social and psychological dimensions that should be implemented in the public spaces, people need to be a part of the creation act, the design process and participate in shaping the space (Gehl and Suarre, 2013). With the involvement of several NGOs and different civil society actors in general, the participatory trend had a drastic increase especially in situations where vacant spaces and urban voids were continuously degenerating the city structure and bringing discomfort to the inhabitants.

The solutions were established by a bottom-up approach, considering local governance and participative democracy, open-source urbanism and other tools and methods. Ideas like hosting events, open sky workshops, ephemeral architecture, short term rental contracts, and temporary use of space aimed to create more liveable and enjoyable spaces in cities. It added more common areas for social interaction and recreation with a healthier and more sustainable framework. Artistic manifestations were again one of the very considerable options for these kinds of projects.

\section{ART TRANSFORMING LIFE IN CITIES}

Art demonstrations in public spaces have increasingly expanded. Contemporary artists were not limited to indoor exhibitions of fixed and static objects. Yet, the artwork itself created a space with its own horizons and generated dynamism and movement around it. As attested by the artists Isabel Cabanellas and Clara Eslava in their research about children and people's relationship to space: "... the urban must be receptacle and motor of human creativity in both senses at the same time. The street becomes, in this way, a plastic space where paradox, dreams, desire, humour, and poetry face all kinds of random and aleatory processes against bureaucracy, utilitarianism and the false spectacularisation of the city" (Cabanellas and Eslawa, 2005:14). Street graffiti, open stages performing arts, sculptures, and other forms of art became part of the urban elements and facilities. The inclusion of the observer in the art exhibition was more highlighted in contemporary art movements. This has, not only, sensitised people to be more and more engaged and concerned with art, but also, it has generated a social experience and an occasion for exchanging ideas and dialogue around the artistic oeuvre. Connecting people from distant lands and cultures is one of the strengths of art (Hulbert, 2018). City space is, in fact, an interface between art and people.

Furthermore, art as a practice must become more participant in the economic structure of the city and its development. As an example of such projects, which aim to revitalise life in the city, different artistic manifestations are organised in different cities of the world. The city of Tunis has been hosting a big number of such projects, especially, in its centre, where the Islamic Medieval town of the Medina is located. This historical site is classified as a UNESCO world heritage since 1979. This Town reflects the collective memory for the Tunisians and is also a singular destination for tourists.

However, this authentic heritage is not receiving considerable maintenance. It is required to accentuate its valorisation, not only concerning its tangible components, but also, to revitalise its intangible values, which are linked to its past and present as well. The question of the preservation of the Medina's heritage should reflect the recognition of the right to the city and the social and functional mix that constitute it (Ammar, 2017).

In order to make the Medina more livable and consider it as a "kinematic" and dynamic historical complex, different associations and contributors have initiated various "nonformal" activities, such as, architecture workshops, associative urban design trainings and also art workshops and festivals. As a matter of fact, the atmosphere of the Medina and its unique urban character potentially favour those various artistic expressions. In the recent years, the city has become an open museum for two biennial artistic workshops, namely, "Dream City" and "Interference".

Dream City is a multidisciplinary festival of contemporary art organised in the Medina of Tunis. It was founded in November 2007 by Tunisian choreographers Selma and Sofiane Ouissi, as a response to the "confiscation" of public space by the totalitarian regime at that time, and against the elitism of the cultural/artistic spaces. This biennial festival has been hosting artistic performances in different corners of the old city of the Tunisian capital. The program contains a mixed variety of trainings, art workshops, exhibitions and features musical concerts. Interference is, as well an artistic manifestation that has its first edition in 2016. This lightart project exhibits different artistic creations curated by national and international artists from different corners of the world (Detfel, 2016).

The spaces of the Medina, the usual ones and the unfrequented ones, bearing socio-cultural symbolism and mysticality, were the inspiration and the canvas for emerging and established, nationals and international artists. The two festivals attracted a great number of attendees of all ages, who stumbled into artistic performances in all corners of 


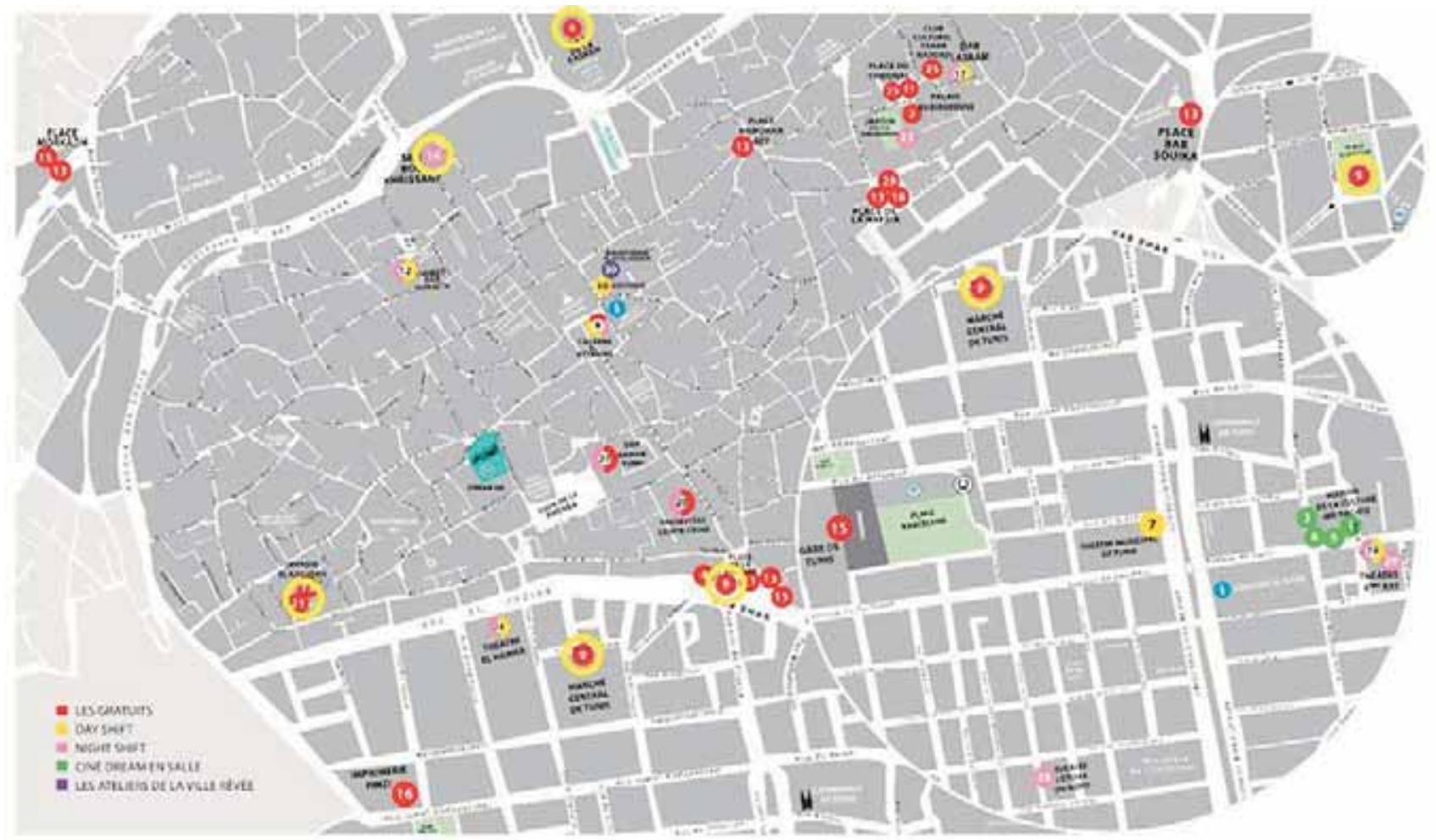

Figure 1: Urban Parcours of Art Projects in Dream City Art Festival (Projects listed in this paper are circled in yellow). Source: https://2019.dreamcity.tn

the old city. Inhabitants of the Medina took part in the event too, which enlightened the sprawling alleys with visual art and music. Community involvement was created by the morning sessions and art workshops spreading everywhere and having the attention of youth. This urban artistic promenade succeeded to connect the population and the visitors with their environment and sensitised them with the land use and function of urban spaces. It was also an initiative to democratise artistic practices and create more social dynamism and dialogue. During the event, the visitors could attend the various art projects through a guided tour. They could also use help of a map (Figures 1 and 2), printed or digital, pointing the location of the different artworks. This created a unique and personalised experience. The impact of this artistic exhibition was witnessed during the period of the festival, and after its closure. In many cases, people stayed connected to the spaces where they had a particular and new experience. The project "El Msab" (the landfill), was a decent illustration of one category of urban transformation from a negative (residual, dirty, unhealthy, dangerous), to a positive state (clean, animated, pleasant, attractive, aesthetic) (Figures 3 and 4).

A recent project was shown in the last edition of Dream
City. A public space located near the limits of the dense traditional tissue, that was considered as a trash dump, attracted the attention of the artist who coordinated with the Tunisian association that is concerned with the artistic and social practices in the Medina of Tunis, called l'Art Rue Association. The site was an inspiration for creating a public square characterised by a vegetal/mineral combination. After cleaning the area, an urban landscape of a modern aspect was created and inspired by the historical context using concrete and wooden elements, graffiti, artistic lighting and video projections (Figures 5 and 6). While nobody was against transforming this area from a trash dump into a clean space, some citizens expressed their rejection to the style manifested in the new square. Their argument was based on the contrast between this space and the Medina's architectural and artistic vocabulary. Nevertheless, most of the habitants appreciated the atmosphere created by adding value to a former non usable space.

A second category on urban transformation was valorising the hidden potential of a certain space, in this case, the open sky yard of Sidi Boukhrissane Mausoleum. This yard was abandoned, useless and undervalued and the artist Robert Sochacki noticed its potential. He worked on this project 


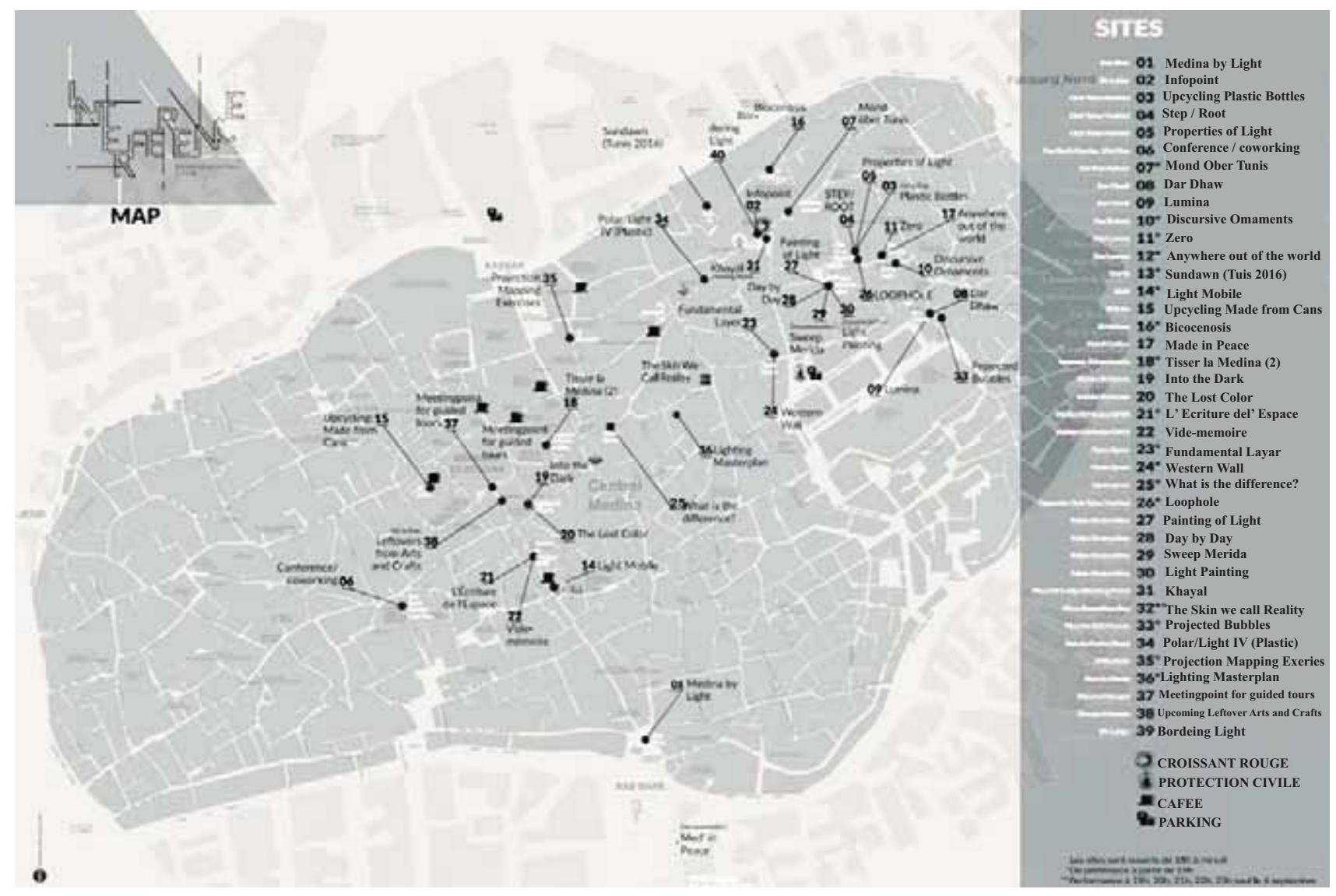

Figure 2: Urban Parcours of Art Projects in Interference Festival (The projects listed in this paper is marked in blue). Source: https://issuu.com/journaldelamedina/docs/merged
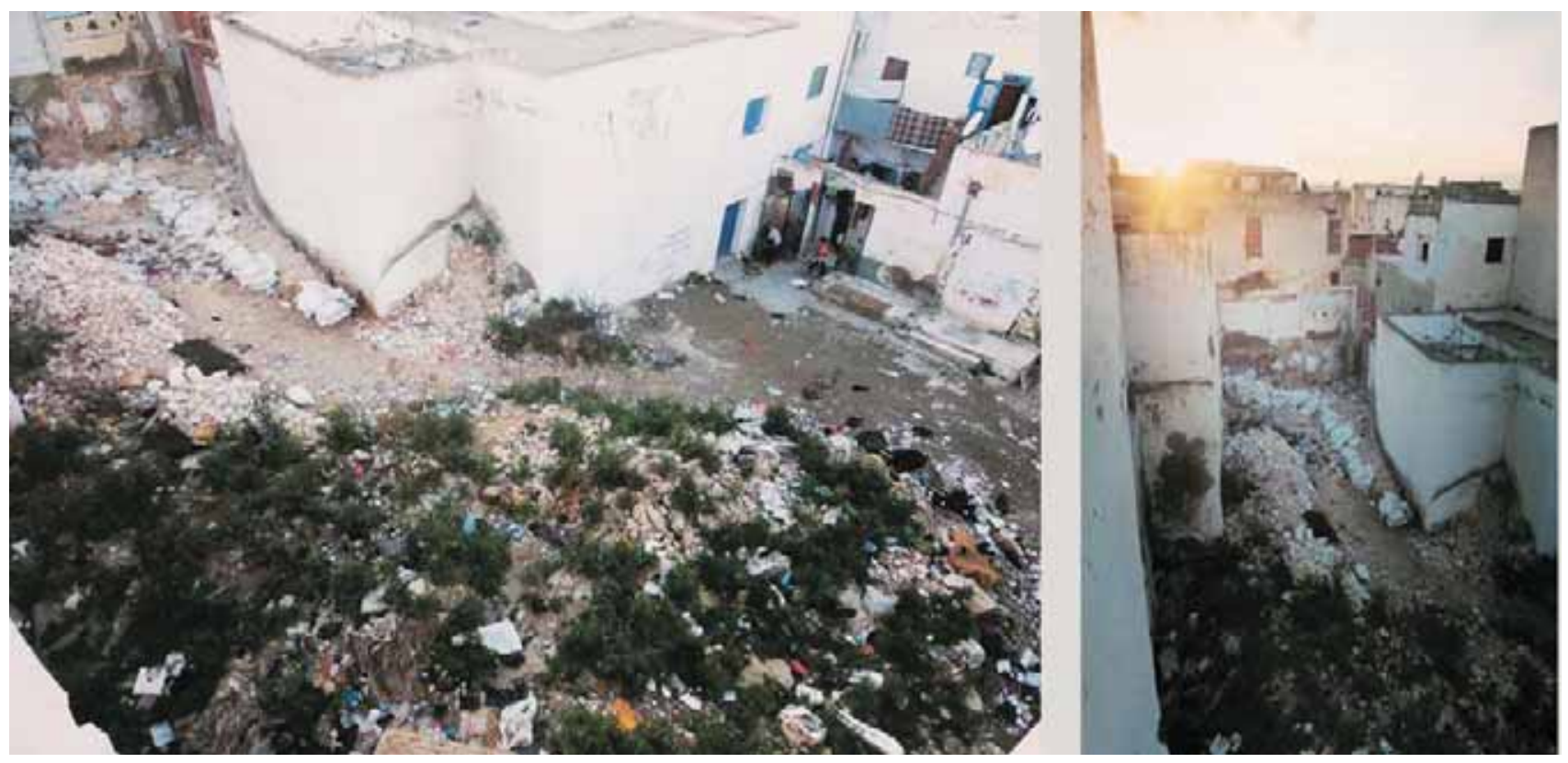

Figures 3 - 4: The Site Before the "El Msab" Project

Source: L'Art Rue Association Facebook page, Pol Guillard Photography 

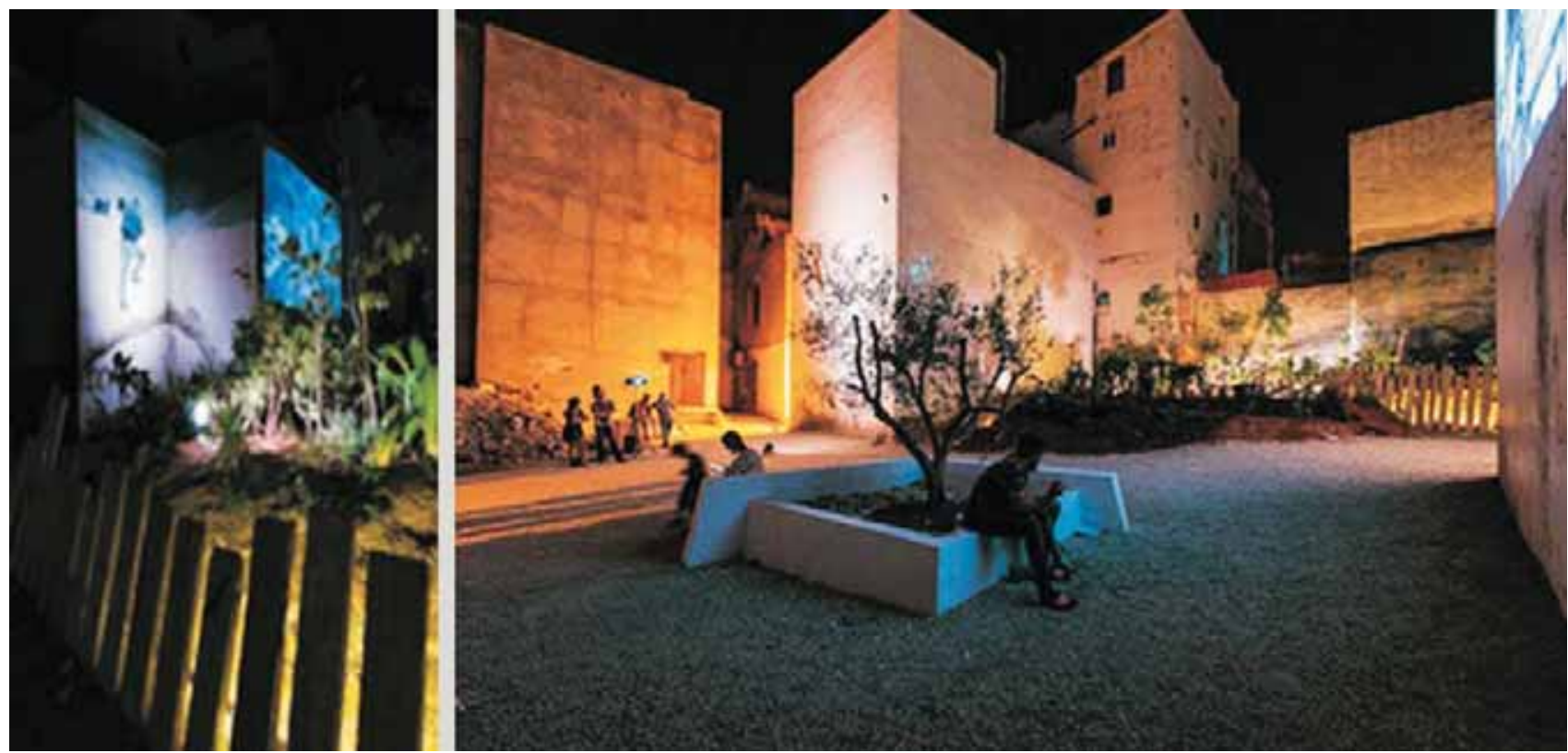

Figures 5 - 6: The site after the "El Msab" project (project number 21 on Figure1 map).

Source: L'Art Rue Association Facebook page, Pol Guillard Photography


Figures 7 - 8: The Mausoleum Yard Animated During Art Festivals (Project number 14 on Figure 1).

Source: L'Art Rue Association Facebook page, Jennifer Braun Photography

and revitalised the area by transforming it into a huge video painting. This project reminded the habitants of the space qualities as a convivial square hosting recreational activities and social interactions. It also inspired local artists to create different types of artworks, keeping the yard more alive than it was (Figures 7 and 8).

The Public Parliament or "El Miad Collectif" was also a project created in the last edition of the Dream city. Artists and architects worked together on a socially engaged project. People were not just participating as observers but were invited to be actively participating in its creation and installation. It also made them the main contributors and the center of the project's concept. The flexible architectural oeuvre was installed in different places in the Medina, in a park, in the periphery of the city, in the gate of Beb Bhar Square, and in different squares and streets as well. In this exposed Parliament, people could freely talk about different topics. It also acted as an open theatre where people could express their feelings and emotions (Figures 9 and 11). These artistic creations essentially generated social interaction and transformed urban life by producing a community-built environment. This intervention also proved that the objective of public art is not simply to "decorate" a public space, but 


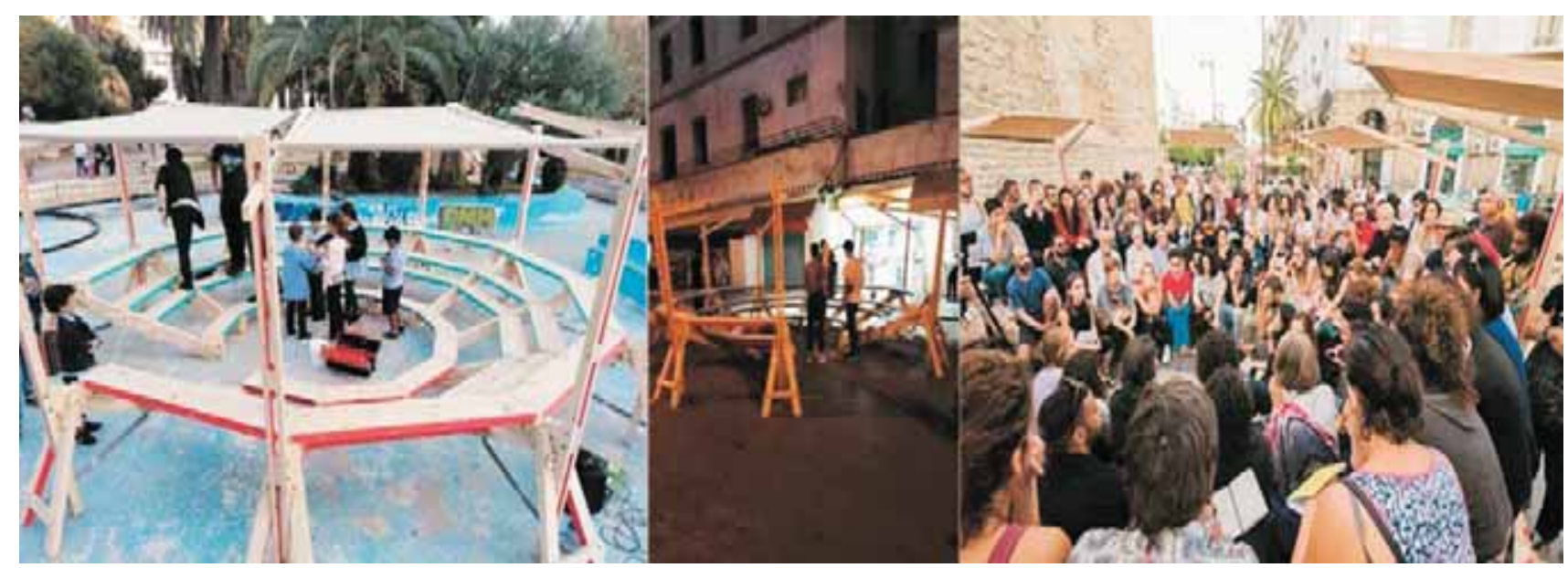

Figures 9 - 11: The Public Parliament in Dream City Festival, its preparation, and installation (project number 9 on different locations in Figure 1 map). Source: Author and L'Art Rue Association Facebook page, Pol Guillard Photography

should rather contribute to building a feeling of community (Brea, 1999). Moreover, art should not ignore the social and political conditions that encounter it. Through curating cities projects, artists can give voice to people in their daily-life spaces, as it may make a direct impact on the political life, especially when it is allied with the social movements. On the other side, this type of project, which is based on social contribution should take into consideration the characteristics of the host space, to avoid any nuisance to the habitant's privacy and acoustic comfort among other factors. Another approach to urban transformation is presented within "Interferences 2018", which also included the citizens in the decision-making process (Figures 12 and 13). The project tends to be an artistic social experiment. Using a less spectacular form of art, Malika Hagemann set the ground for the inhabitants and visitors to be the real artists. With some candles, small furniture and tools, she spread mini workshops in different alleys, squares and corners of the Medina. In this cozy meditation-like atmosphere, the visitors were invited, guided by some questions, to express their feelings, desires, aspirations. The expression is absolutely free, varying from poetry and prose to sketches and drawing. While collecting the citizen's artworks, Malika had a considerable database of the people's opinions regarding their neighbourhoods. Indeed, this method gained its share in social analysis. The findings of this artsy "social experiment" were used, or at least taken into consideration, to decide the future of certain spaces more democratically with a bottom-up style. The artist chose a subtle art installation to stimulate urban change through a more elaborate approach, which was both participatory and strategic. The bigger part of the impact of this artwork was not directly detected nor foreseen, yet it was very significant, deep and well oriented and the "scientific relevance" of the project did not decrease its artistic value by any means.

\section{CONCLUSION}

The artistic collectives existing in the city were destined to be a network for the linkage and urban regeneration, with the aim of creating a deeper relationship with the space in the scale of the neighborhoods, playing a crucial role in structuring the public urban domain.

The design of transitional spaces, meant primarily for mobility purposes, is nowadays evolving into a process focusing on attractiveness, complexity and multifunctionality. This approach is trying to shift a major part of urban identity, the memory of spaces based on city transformations (Amato and Bevilaqua, 2020).

Embellishing the urban scene of the Medina with artistic installations and performances, these curatorial projects moved away from the routine of life in the city and opened the horizons for new social and emotional experiences. Spontaneous, irrational, bizarre and out of common, these artworks certainly caused interferences and bouleversements on the observers and participants and thereafter affected and influenced them (Hlavajova, 2008). Thus, through the individual and collective experience in a particular space, the user changed his perception and drew a different mental image after that the space had been transformed with artistic effects and sceneries. On the other hand, these exhibitions had an impact on space usage, as they contributed to the production of urban spaces and shaped the social life that was boosted and enhanced during the event. In fact, art nurtured community building because it gathered together from different social backgrounds ideologies and cultures. 

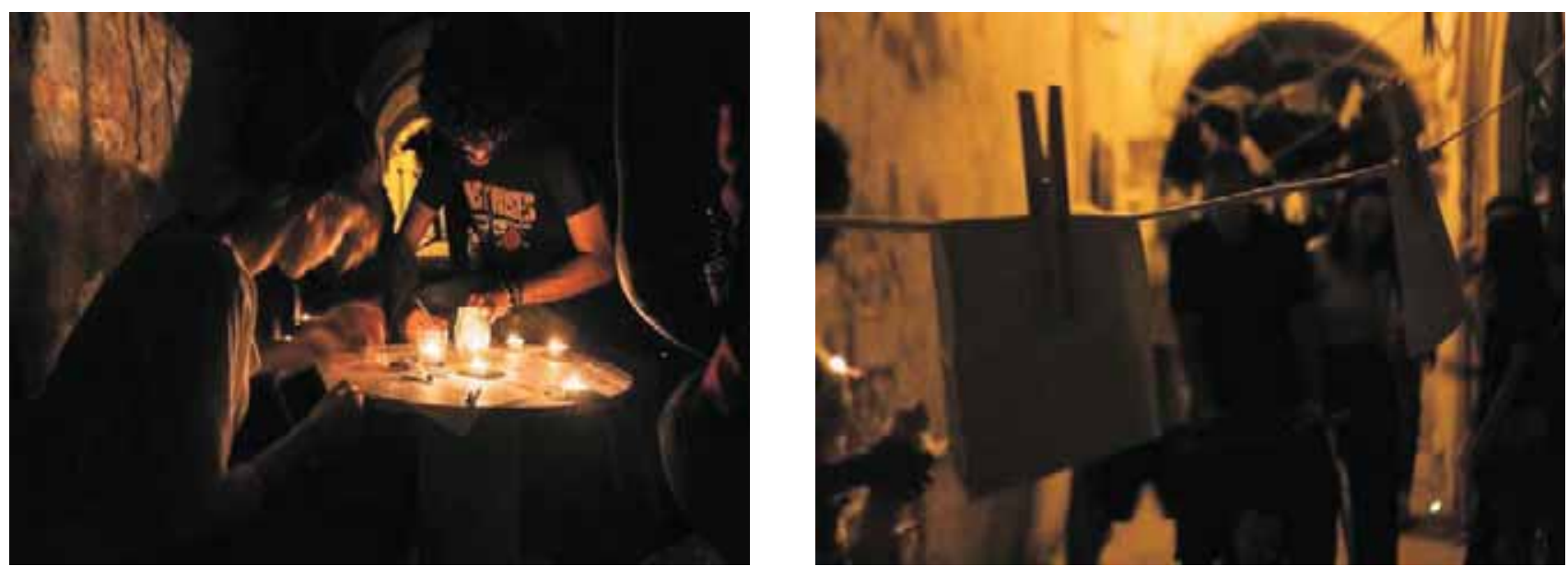

Figures 12 - 13: A Creative Socially Inclusive Installation in Interference Art Project (marked in blue in Figure 2 map, located in Achour Street). Source: L'Art Rue Association Facebook page, Alpha Bakemono Photography

To highlight the outcomes of such projects, numerous examples of art installations have been selected. These have directly and radically changed life in devaluated and deserted places. The "El Msab" project and the Sidi Boukhrissane Mausoleum light performance injected more life in these public places during and after these artistic manifestations. While for the other listed cases, the social dimension was considered as a priority. In fact, through creative and innovative approaches, people were invited to be part of the projects and freely expressed their feelings and desires in an unusual frame. Art was a way to evoke and arouse people's imagination and liberate their thoughts. It was also used for engaged artists, as a means to evoke debate on different topics related to politics, climate change challenges and social inequity. These projects had tangible and intangible impacts on the city and transformed the usage of certain public places.

Although the historical specificity of the Medina, as well as the touristic factor, were already putting pressure on the urban infrastructure, this kind of congested festivities added more urban pressure. These artistic initiatives considered the importance of the historical stamp, the fluidity and functionality of the city fabric, and respected the responsivity of the habitants. As a consequence, the planning of the public domain became a foundation of urban regeneration including design solutions for sustainability and resilience, prioritising the flexibility of the public space, characterised by social interactions (Amato and Bevilacqua, 2020).
Moreover, these projects contributed to the decrease in the crime rate of the area. According to an empirical study about urban security and practices related to insecurity in the Medina, led by a group of Tunisian researchers, establishment of social relationships were important variables explaining the improved security conditions. In one of his interviews, "El Ghali", emphasised that the artistic practices in the Medina contributed in creating an environment for youth to use their energy in a positive way through artistic expressions instead of violence and excessive drug consumption (El Ghali, 2018). As it also created social bonding and interaction between inhabitants and the visitors.

However, despite the importance of these artistic manifestations and their impact on the public life, such projects rarely happen internationally. A compromise between these non- formal bottom-up interventions and official master plan projects prepared by the municipalities and other governmental organizations is needed to arrive at a coherent and effective public space intervention, as in the Medina. For example, some projects such as "El Msab" (Figures 3 -6 ) were meant to be integrated in official design schemes and plans, permitting a continuous and coherent networking of designed green and public spaces eligible to host artistic creations

Finally, there are undoubtedly countless innovative ways in transforming our cities for better living spaces. Cities are the world which we created; they are also the world in which we henceforth live (Park, 1967). 


\section{REFERENCES:}

Ammar, L., 2017, “Les Enjeux Du Patrimoine Ancien Et Récent à Tunis," Aux XIXe et XXe siècles, Entre Volontés de Sauvegarde et Périls, in Al-Sabïl, Revue d'Histoire, d'Archéologie et d'Architecture Maghrébines, No 3.

Amato, C., Bevilacqua, G., June 2020, “The Role of Art for the Regeneration of the Public City", The Experiences of the Metropolitan Cities of Palermo and Naples, XVIII International Forum, World Heritage and Contamination, Naples 11 Capri 12/13.

Ben Salem, S., 2019, “The Medina of Tunis Facing the Modern City Tangible, Intangible and Social Values in an Arabic Old City," AMPS Proceeding series: Tangible - Intangible Heritage(s) Design, Social and Cultural Critiques on the Past, the Present and the Future, No 15

Bandarin, F and Van Oers R., 2014, Reconnecting the City: The Historic Urban Landscape Approach and the Future of Urban Heritage, London, Wiley-Blackwell.

Brea J.L., 1999, Transformaciones Contemporáneas de la Imagen-Movimiento: Postfotografía, Postcinema, Postmedia, translated by Menéndez L G, in Revista Acción paralela, No. 5.

Cabanellas, I. and Eslava, C., 2005, "En Busca Del Espacio Perdido: en Territorios de la Infancia,” Diálogos Entre Arquitectura Y Pedagogía, translated by Menéndez L G, Graó, Barcelona.

Detfel, H., 2016, "Interference: Why do We Work in Site-Specific sites," Journal de la Medina, vol 5:10.

El Ghali, A., Turkey, Y., 2018, “A Study on Urban Security in the Medina of Tunis,” Dignity Publication Series on Torture and Organised Violence Praxis Paper, No. 21.

Giovannoni, G., 1998, L'urbanisme Face aux Villes Anciennes, translated by Petita A, Tandille C, Mandosio J-M, Paris, du Seuil.

Gehl J., 2001, Life Between Buildings: Using Public Space, Translated by KOCH, Washington, Covelo, London, Island Press.

Gehl, J. and B. Suarre, 2013, How to Study Public Life?, translated by Steenhard Karen Arm, Washington, Island Press.

Hulbert, TW., 2018, "Curating Inclusive Cities through Food and Art”, Multimodal Technologies Interact, vol 2:44-46.

Hlavajova, M., 2008,"From Emergency to Emergence," in Art as a Public Issue, How Art and its Institutions Reinvent the Public Space, edited by Jorinde S. Cahier on Art and the Public Domain, No. 14.

Jacobs, A and Appleyard, D., 1987, “Toward an Urban Manifesto”, Journal of American Planning Association, vol 53(1):112120.

Jacobs, J., 1960, The Death and Life of American Cities, NewYork, Random House.

Kostof, S., 1991, The City Shaped: Urban Patterns and Meanings Through History, London, Boston, Toronto, Little, Brown and Company.

Park R., 1976, On Social Control and Collective Behaviour, Chicago, Chicago University Press. 